\title{
Physiological Response of Thallasia hemprichii on Antrophogenic Pressure In Pari Island, Seribu Islands, DKI Jakarta
}

\author{
Aditya Hikmat Nugraha1,2*, Dietriech G Bengen ${ }^{1}$ and Mujizat Kawaroe ${ }^{1,3}$ \\ ${ }^{1}$ Marine Science and Technology Department, Bogor Agricultural University \\ Kampus IPB Dramaga Bogor, Jl. Raya Dramaga, Bogor, Jawa Barat 16680 \\ 2 Indonesian Seagrass Foundation, \\ Gedung Lembaga IImu Pengetahuan Indonesia, J. Raden Saleh No.43 Jakarta Pusat \\ ${ }^{3}$ Surfactant and Bioenergy Research Centre, Bogor Agricultural University \\ Kampus IPB Baranangsiang, JI. Pajajaran No.1 Bogor, Jawa Barat \\ Email: adit.marine@gmail.com
}

\begin{abstract}
Seagrass ecosystems is one of the tropical marine ecosystems that have important functions, among others as a feeding and nursery ground for marine life. Anthropogenic stress is one of the threats that may inhibit the survival of seagrass ecosystems. This study examines the effects of anthropogenic pressures on physiological responses of seagrass Thalassia hemprichii at several different locations in Pari Islands. Physiological responses studied were leaves and rhizome growth, bioaccumulation of heavy metals and histological tissue analysis on seagrass. The results showed that the growth response of seagrass has a positive correlation with the nutrients in the environment. Seagrass leaf growth is highest at Station 2 (4.16 mm.day $\left.{ }^{-1}\right)$ and rhizome growth is highest at Station $4\left(1.3 \mathrm{~mm}\right.$.day $\left.{ }^{-1}\right)$. Seagrass accumulate heavy metals from the environment and accumulation of heavy metals is highest on $\mathrm{Pb}$. There is no correlation between the concentration of heavy metals in the seagrass and environment. The results of histological analysis showed that there was no damage to the tissue of seagrass leaf and rhizome.
\end{abstract}

Keywords : Bio-acumulation, Growth, Physiology, Seagrass, Thalassia hemprichii

\section{Introduction}

Seagrass community is one of coastal ecosystem which has important ecological functionsuch as food source for coastal community and marine sediment stabilization (Koch et al., 2012; Christianen et al., 2013) and as feeding area for several marine biota (Heck et al.,2003; Van Tussenbroek et al.,2006; Christianen et al., 2014; Kawaroe et al.,2016a). Seagrass also plays important role in carbon cycle (Mcleod et al., 2011). Research of Rustam (2014) showed that seagrass can absorb carbon dioxide gas from atmosphere as much as 31,.08-41,73 MgC.ha-1.

Pari Island is located in the Seribu Islands that have multi species seagrass ecosystems. Research by Kawaroe et al. (2008) and Rustam (2014) stated that the abundance of seagrass in Pari Island declined recently. Pari Island is closed to the Jakarta Bay which face heavy anthropogenic pressures from the 13 rivers that flow into the Jakarta Bay. As Seribu Islands Region is one of tourism destination, so many activities give threat to coastal ecosystem sustainability, such as construction activities to provide tourism facility, tourist activities, etc. Anthropogenic pressures on the aquatic environment is showed by increasing nutrients concentration in the water and sediment. It shoed that nitrate and phosphate have increased quite dramatically (Burkholder et al., 2007). Anthropogenic pressures on the water environment is also noticeable by the presence of heavy metals content in the water and it may affect seagrass community (Waycott et al., 2009). Therefore further studies need to be conducted on the impacts of anthropogenic activities to seagrass community in the Pari Island. Anthropogenic pressures may give impact to the physiological of seagrass. Physiological responses that can be observed according to Udy and Dennison (1997) include seagrass growth, biomass, and percent cover. The observation physiology response of sea grass was conducted on Thalassia hemprichii because this species is cosmopolitan types and easily found in Indo-Pacific region (Short et al., 2007). Moreover, this species has highest percent cover in Pari island (Kawaroe et al., 2016b) The purpose of this study was to observe physiological response of seagrass i.e. growth, heavy metal content and leaf and 
rhizome tissue condition based on histological analysis.

\section{Materials and Methods}

The study was conducted in Pari Island from December 2014 to April 2015. There are 4 observation station, based on the human activities and their residences. Station 1, and 2 were located in south-east and south-west of Pari Island, while Station 3 and 4 were located in south and north of Tikus Island. Water and sediment parameter quality were measured at Laboratory of Environment Productivity, Faculty of Fisheries and Marine Science, Bogor Agricultural University. Seagrass tissue histology analyses was prepared at Histopathology Laboratory, Faculty of Veterinary Medicine, Bogor Agricultural University.

Water quality parameters were measured in situ includes temperature, dissolved oxygen (DO), $\mathrm{pH}$, salinity, clarity and current speed. Water quality parameters were performed ex situ include nutrients (nitrate and phosphate), heavy metals ( $\mathrm{Pb}, \mathrm{Cd}, \mathrm{Cu}$ ), DO and COD. Observation water quality parameters in Laboratory using the APHA (2012). Analysis of sediment carried out in the laboratory which includes analysis of sediment fractionation using a Pipette method, CNP content analysis and analysis of heavy metals (Pb, Cd, Cu) using the APHA (2012).

\section{Seagrass Growth Observation}

The samples of Thalassia hemprichii were taken using purposive sampling method. Measurement of rhizomes and leaves growth was done in tagged rhizomes and leaves. The rhizome was marked using cable ties and a newtop paper which attached around the base of last bud (Short and Duarte., 2001) (see Figure 2). The seagrass growth was measured every 14 day for 3 months and is calculated using following formula (Short and Duarte, 2001)

$$
P=\frac{P_{t}-P_{0}}{t}
$$

$\mathrm{P}=$ Growth of rhizome/leaves $\left(\mathrm{mm}^{\mathrm{day}}{ }^{-1}\right)$

$P_{t}=$ Length of rhizome/leaves in $t_{14}$

$\mathrm{P}_{0}=$ Length of rhizome/leaves in $\mathrm{t}_{14-1}$

$\mathrm{t}=$ interval time of observation (14 day)

\section{Histological Analysis}

Samples of the seagrass were collected and transported to the laboratory. Fragments of $1 \times 1.5$ $\mathrm{cm}^{2}$ were transvered cut from the seagrass leaves and rhizome and were immediately fixed in $70 \%$ F.A.A. for 24 hours. They were then submitted to dehydration by soaking in a series of solutions $n-$ Butanol and embedded in paraffin wax according to the usual techniques utilized in plant anatomy. Sections $(5 \mu \mathrm{m})$ were obtained in a microtome and stained with eosin. (Saas, 1951). The slides of the seagrass histology preparat were observed using the microscope

\section{Heavy metals Content in Seagrass and Sediment}

Dried seagrass was crushed, took as much as 2 grams, then put into a $100 \mathrm{ml}$ beaker glass, added $10 \mathrm{ml} \mathrm{HNO}_{3}$ and heated using a hotplate at a temperature of $85^{\circ} \mathrm{C}$ until the volume remain $1-2 \mathrm{ml}$ then cooled and added $10 \mathrm{ml}$ of $\mathrm{HNO}_{3}$, aand $10 \mathrm{ml}$ $\mathrm{HClO}_{4}$. Samples tehn were homogenized and heated on a hotplate until the steam was missing. If the solution is already clear, add $100 \mathrm{ml}$ of distilled water and homogenized, then filtered (APHA, 2012) and analyzed using AAS (detection limit of 0.001 ppm).

\section{Result and Discussion}

\section{Physical and Chemical Water Condition}

Physical and chemical conditions of the waters in the observation station generally were in good quality standard values for water (Table 1). Several chemical parameters of waters have exceeded value such as nitrates, phosphate, COD and heavy metals (Table 1). Refer to Environmental Ministry Regulation No. 51-2004, standard value for nitrate and phosphate in water should less than

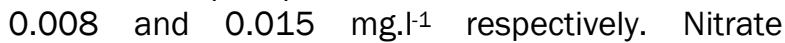
concentrations in Stations 1, 2 and 4 as well as orthophosphate concentrations in stations 1, 2 and 3 were exceeded those standart. Those may be due to domestic waste and coral erosion as one of phosphate source in waters (Effendi, 2003).

Refer to Environmental Ministry Regulation No 51-2004, standard value for heavy metal concentration of $\mathrm{Pb}$ and $\mathrm{Cu}$ in seawater should less than 0.008 mg..$^{-1}$, and $\mathrm{Cd}$ concentration no more than 0.001 mg..$^{-1}$. Pb, $\mathrm{Cu}$ and $\mathrm{Cd}$ concentration in all station have a value bellow standard. The results sediment fractionation showed that sediment was mainly consisted of sand (more than 90\%), followed by silt and clay respectively. The analysis of sediments showed that phosphorus has the highest concentration and then followed by carbon and nitrogen (Table 1). Refer to standard value for heavy metal concentration in sediments of Canadian 
Council of Ministers of the Environment (CCME) (1991) the content of $\mathrm{Cd}, \mathrm{Pb}$, and $\mathrm{Cu}$ should less than 0.006, 22, and 30 ppm respectively. Concentration $\mathrm{Pb}$ and $\mathrm{Cd}$ in sediment at all stations (Table 1) were exceeded those standard. High of heavy metal concentration in marine sediment may accumulate and give toxic effect for marine benthic organism (Ahmad, 2009).

Based on concentration of nutrients and COD it showed (Table 1) that the station 1, 2 and 4 have been polluted environment since they were exceeded the water quality standard (Effendi, 2003).

\section{Seagrass Growth}

Thalassia hemprichii leaves have faster growth than rhizome because rhizome has a morphological structure thicker than leaf therefore it need more time to grow (Vonk et al., 2015; Kawaroe et al., 2016a) (Table 2). The highest average growth of seagrass leaves was from station 2 (4.16 $\mathrm{mm}$ day $^{-1}$ ) (Figure 3 ). This is presumably due to higher nutrients concentration in the station 2 compared to other stations.

Based on the results obtained at each station seagrass growth is directly proportional to the concentration of nutrients contained in water. It shows that the seagrass leaf growth as response to nutrient content in the water. Nutrients are among the factors that affect growth (Zhang et al., 2014).

Other studies related Thalassia hemprichii leaf growth was conducted by Kiswara (2010) in Pari Island, showed in the range of 0.1 to $6.3 \mathrm{~mm}^{\text {day }}{ }^{-1}$, with the largest growth rate happened on the first leaves $\left(6.3 \pm 1.4 \mathrm{~mm}^{\left.- \text {day }^{-1}\right)}\right.$ and the lowest in the fifth leaf $\left(0.1 \pm 0.1 \mathrm{~mm} \cdot \mathrm{day}^{-1}\right)$. During east monsoon (July 2009) the growth rate of $T$. hemprichii leaves

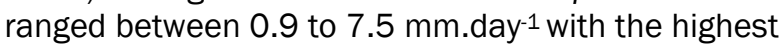
growth rate on the first leaves of $7.5 \pm 1.0 \mathrm{~mm}^{- \text {day }^{-1}}$ and the lowest was 0.9 mm.day $^{-1}$ (Kiswara, 2010).

Table 1. Physical and chemical parameter condition in reserach location

\begin{tabular}{|c|c|c|c|c|}
\hline $\begin{array}{l}\text { Physic and Chemical } \\
\text { Water Parameter }\end{array}$ & $\begin{array}{l}\text { East of Pari } \\
\qquad(\mathrm{St} 1)\end{array}$ & $\begin{array}{l}\text { West of Pari } \\
\text { (St 2) }\end{array}$ & $\begin{array}{c}\text { South of Tikus } \\
\text { (St 3) }\end{array}$ & $\begin{array}{c}\text { North of Tikus } \\
\text { (St 4) }\end{array}$ \\
\hline \multicolumn{5}{|l|}{ Water } \\
\hline Temperature ( $\left.{ }^{\circ} \mathrm{C}\right)$ & 31-34 & $30-32$ & 29-33 & 29-32 \\
\hline $\mathrm{pH}$ & 7.8 & 8.4 & 8.6 & 9.1 \\
\hline $\mathrm{DO}(\mathrm{ppm})$ & 7.02 & 7.25 & 9.4 & 9.6 \\
\hline Clarity (\%) & $100 \%$ & $100 \%$ & $100 \%$ & $100 \%$ \\
\hline Salinity (psu) & 33.67 & 33 & 33 & 34 \\
\hline Nitrate $\left(\mathrm{mg} . \mathrm{l}^{-1}\right)$ & 0.032 & 0.09 & 0.007 & 0.048 \\
\hline Orthophosphate ( mg.l-1 $)$ & 0.029 & 0.032 & 0.027 & 0.01 \\
\hline $\operatorname{COD}\left(\mathrm{mg} . \mathrm{I}^{-1}\right)$ & 21.98 & 21.98 & 18.32 & 29.31 \\
\hline Depth (cm) & 45 & 15 & 50 & 70 \\
\hline Current(m.s-1) & 0.083 & 0.07 & 0.028 & 0.053 \\
\hline \multicolumn{5}{|l|}{ Heavy metal } \\
\hline $\mathrm{Pb}\left(\mathrm{mg} . \mathrm{I}^{-1}\right)$ & not detected & not detected & not detected & not detected \\
\hline $\mathrm{Cd}\left(\mathrm{mg} . \mathrm{I}^{-1}\right)$ & not detected & not detected & not detected & not detected \\
\hline $\mathrm{Cu}\left(\mathrm{mg} . \mathrm{I}^{-1}\right)$ & 0.005 & 0.007 & not detected & not detected \\
\hline \multicolumn{5}{|l|}{ Sediment } \\
\hline \multicolumn{5}{|l|}{ Grain size } \\
\hline Sand (\%) & 95 & 96 & 90 & 96 \\
\hline Silt (\%) & 3 & 2 & 4 & 1 \\
\hline Clay (\%) & 2 & 2 & 6 & 1 \\
\hline Carbon organic (\%) & 0.23 & 0.26 & 0.11 & 0.27 \\
\hline Nitrogen organic (\%) & 0.03 & 0.03 & 0.01 & 0.03 \\
\hline Phosphor organic (\%) & 1.4 & 0.9 & 0.9 & 1.1 \\
\hline $\mathrm{C}: \mathrm{N}$ & 8 & 9 & 9 & 9 \\
\hline \multicolumn{5}{|l|}{ Heavy metal } \\
\hline $\mathrm{Pb}\left(\mu \mathrm{g} \cdot \mathrm{g}^{-1}\right)$ & 49.84 & 40 & 27.64 & 29.11 \\
\hline $\mathrm{Cd}\left(\mu \mathrm{g} \cdot \mathrm{g}^{-1}\right)$ & 5.11 & 6.32 & 2.17 & 2.29 \\
\hline $\mathrm{Cu}\left(\mu g \cdot g^{-1}\right)$ & 5.34 & 11.17 & 2.48 & 2.62 \\
\hline
\end{tabular}




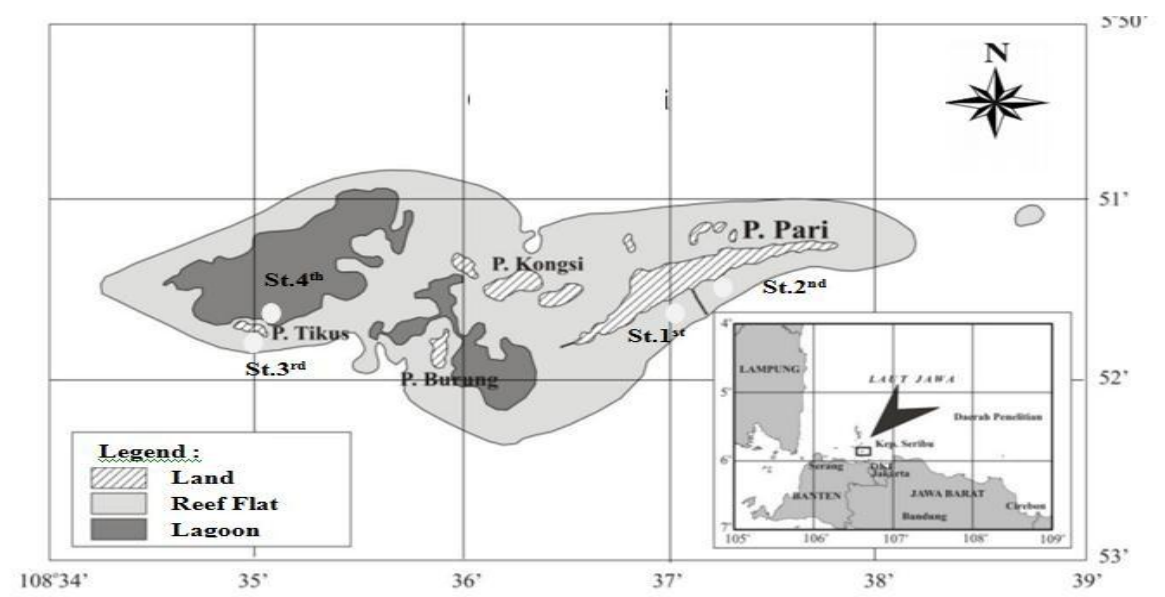

Figure 1. Research Location of Pari and Tikus Island
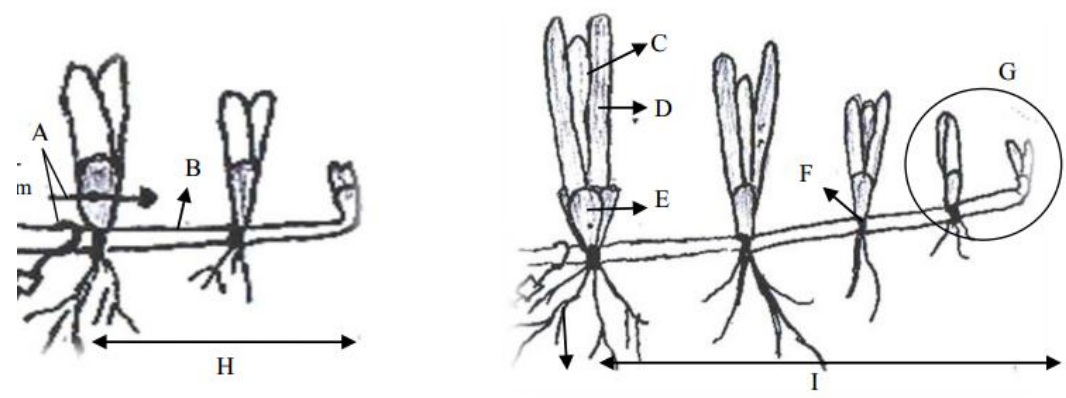

Figure 2. Seagrass growth illustration

Note. A : mark to determine the growth, B : Rhizome, C: New leaf, D : Old leaf, E : Leaf sheath, F : Node, $G$ : New Shoots, $H$ : Seagrass extension before growth, I : Seagrass extension after growth

Table 2. Growth (mm.day-1) of Thalassia hemprichii during observation (84 day)

\begin{tabular}{ccccccccc}
\hline \multirow{2}{*}{ Observation } & \multicolumn{7}{c}{ Growth $\left(\mathrm{mm}\right.$. day $\left.{ }^{-1}\right)$} \\
\cline { 2 - 9 } & \multicolumn{2}{c}{ Station I } & \multicolumn{2}{c}{ Station II } & \multicolumn{2}{c}{ Station III } & \multicolumn{2}{c}{ Station IV } \\
\cline { 2 - 9 } & Leaf & Rhizome & Leaf & Rhizome & Leaf & Rhizome & Leaf & Rhizome \\
\hline 14 day & 3.30 & 0.40 & 4.20 & 1.39 & 3.30 & 1.60 & 3.30 & 1.01 \\
28 day & 3.57 & 0.35 & 5.19 & 0.80 & 3.19 & 1.53 & 3.42 & 1.08 \\
42 day & 2.59 & 0.29 & 5.18 & 1.48 & 4.68 & 1.36 & 2.60 & 1.42 \\
56 day & 3.88 & 0.63 & 3.41 & 1.10 & 2.53 & 1.56 & 2.80 & 2.72 \\
70 day & 5.03 & 0.57 & 3.15 & 1.08 & 0 & 0.72 & 2.52 & 0.65 \\
84 day & 5.01 & 0.46 & 3.80 & 0.73 & 0 & 0.78 & 2.63 & 0.93 \\
\hline
\end{tabular}

Rhizome growth was marked by increasing its length, which is characterized by the emergence of new shoots. Rhizome have a very important role in vegetative propagation in seagrass (Vonk et al., 2015). Vegetative reproduction is very important in the process of deployment of seagrass. The higest average rhizome growth was happened at station 3 (1.3 mm.day-1). Besides affected by the depth of water, the rhizome growth was increased with increasing ratio of carbon and nitrogen $(\mathrm{C}: \mathrm{N})$ in the sediment. $\mathrm{C}$ and $\mathrm{N}$ as sediment nutrient may stimulate seagrass growth (Lee and Dunton, 1997; Short, 1983). Depth was related to exposure of the air and affect the growth of seagrass. The more exposed to the air the slower rhizome growth and can cause death of seagrass (Unsworth et al., 2011; Zhang et al., 2014). Rustam (2014) reported that $T$. hemprichii rhizome growth was $1.85 \mathrm{~mm}_{\text {.day-1, while }}$ Vermaat et al (1995) reported that seagrass rhizome growth on the Island of Silaqui and Pislatan 


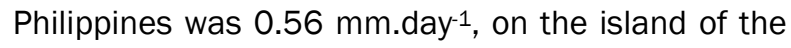
Philippines Kalayah was 1.26 mm.day ${ }^{-1}$ (Rollon et al., 2001), and in Hainan Island of China was to 0.73 mm.day-1 (Zhanzhou et al., 2009).

\section{Bioaccumulation of Heavy Metals}

The seagrass can accumulate $\mathrm{Pb}, \mathrm{Cd}$ and $\mathrm{Cu}$ from the environment. Accordance to Li et al. (2007) the seagrass has ability to absorb heavy metals from the environment and acts as a very good bioindicators for environmental quality monitoring (Lee et al., 2004). The heavy metal concentration in $T$. hemprichii is presented in Figure 4.

Based on the function for organism, heavy metals divided in two classes, they are essential and non-essential heavy metal (D'Souza et al.,2002). Essential heavy metal is a heavy metal needed by the organism for growth process, for example $\mathrm{Cu}$. Non-essential heavy metals are heavy metals which are not needed by the organism for growth process when accumulate in tissues of organism, for example $\mathrm{Pb}$ and $\mathrm{Cd} . \mathrm{Pb}$ on $T$. hemprichii tissue was 1.85-8.45 $\mu \mathrm{g} . \mathrm{g}^{-1}$ and the highest value was found in T. hemprichii located at station 2. Referring to the Canadian Council of Ministers of the Environment (CCME) (1991), the threshold for Pb was 22 ppm, the value of the bioaccumulation of heavy metals $\mathrm{Pb}$ on $T$. hemprichii tissue in Pari island is still below those standard value.

Refer to the Canadian Council of Ministers of the Environment (CCME) (1991), the threshold for $\mathrm{Cd}$ is $0.006 \mathrm{ppm}$ and it is found that the concentration of $\mathrm{Cd}$ accumulation in $T$. hemprichii tissue of Pari island has exceeded of quality standards. $\mathrm{Cu}$ has a bioaccumulation in range 1,3$2,55 \mu \mathrm{g} \cdot \mathrm{g}^{-1}$. Heavy metals $\mathrm{Cu}$ is useful for tissue growth, especially for plant leaf tissue (Kamaruzzaman et al., 2008) and it need 5-20 $\mu \mathrm{g} . \mathrm{g}^{-1}$ for plant to grow normally. When the $\mathrm{Cu}$ concentration in plant tissue more than $10 \mu \mathrm{g} . \mathrm{g}^{-1}$, it can be toxic for plants and the growth becomes stunted (Alloway and Ayres, 1995).

Concentrations of $\mathrm{Pb}$ in seagrass tissue were higher than $\mathrm{Cd}$ and $\mathrm{Cu}(\mathrm{Pb}>\mathrm{Cu}>\mathrm{Cd})$, because many of $\mathrm{Pb}$ sources found in environment such as from ship fuel combustion because there are many shipping activity like fishing boats, tourist boats and commercial vessel. In addition, $\mathrm{Pb}$ has low solubility in sea water, so that $\mathrm{Pb}$ has passive and low translocation from the roots to other plant organs. $\mathrm{Pb}$ have high toxicity and are toxic to other species (MacFarlane and Burchett, 2002).

According to Alutoin et al. (2001) bioaccumulation of heavy metals in seagrasses influenced by environmental condition such as $\mathrm{pH}$ waters and sediments, sediment particle size, temperature, salinity and nutrient content in the water, and season. But in present work, the concentration of heavy metals in seagrasses tissue have not correlation with concentration of heavy metals in environment. Increased bioaccumulation of heavy metal will give toxic and resistant effect for seagrass (Maclnnis-Ng and Ralph, 2004). Heavy metals in seagrass may accumulate in seagrass grazing biota (Govers et al., 2014).

\section{Histological Analysis of Seagrass}

Observation on histological leaf and rhizome tissue was conducted on leaf epidermis and mesophil, rhizome tissue, cortex and stele. Seagrass epidermis tissue have important function in photosynthesis process, because it has high content

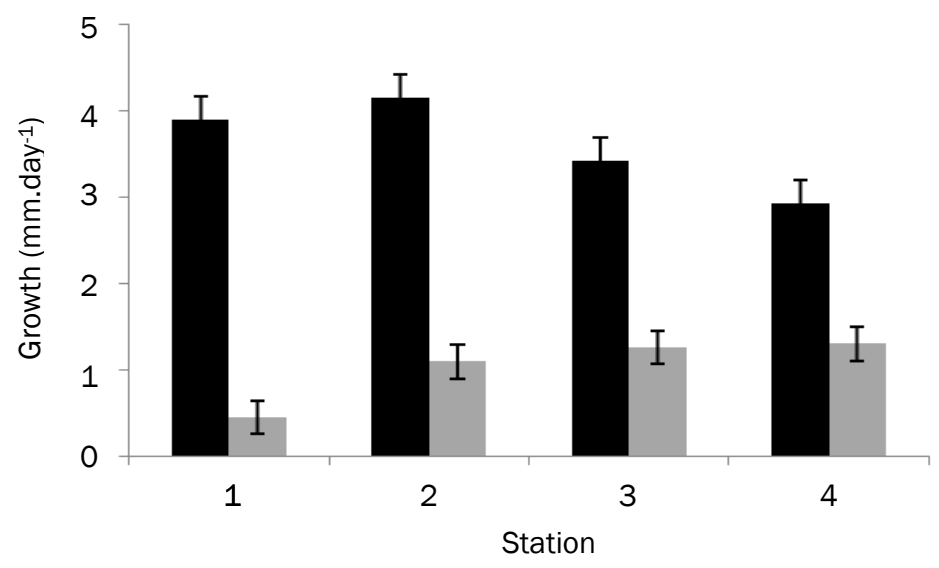

Figure 3. Average of Thallasia hemprichii growth (mm.day-1) during 2 month observation

Note. $\square$ : leaf, $\square$ : rhizome 


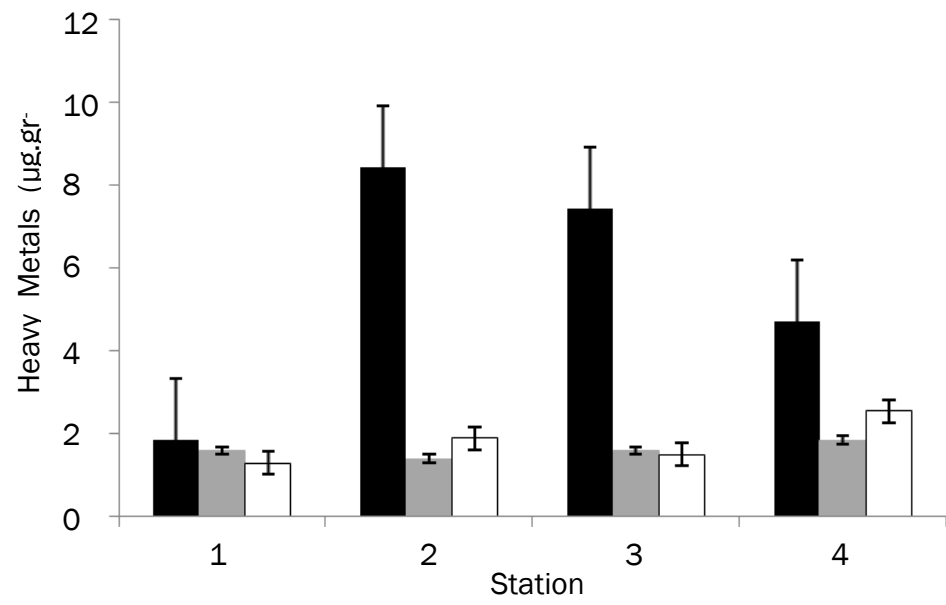

Figure 4. Heavy Metals concentration ( $\left.\mu \mathrm{g} \cdot \mathrm{g}^{-1}\right)$ in Thalassia hemprichii Note. $\square: \mathrm{Pb}, \square: \mathrm{Cd}, \square: \mathrm{Cu}$

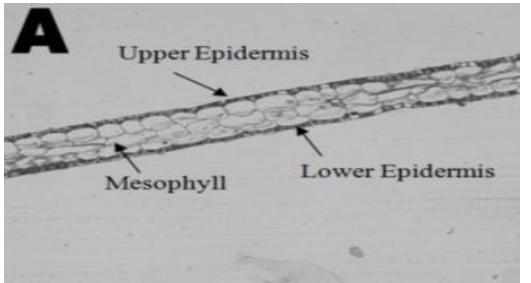

Station 1

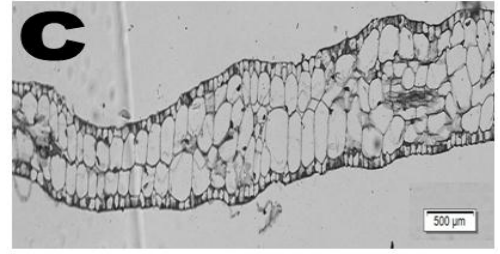

Station 3
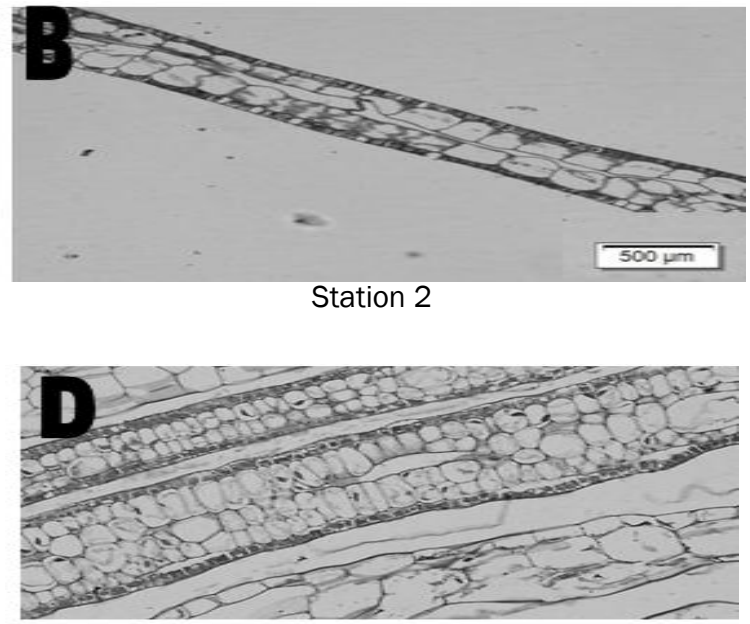

Station 4

Figure 5. Histological sampel of Seagrass leaf tissue Thalassia hemprichii

of chloroplasts (Kuo and den Hartog., 2006). Range of leaf epidermis thickness are 96-114 $\mu \mathrm{m}$. Seagrass leaf epidermis also consists of mesophyll cells containing lacunae. Lacunae was connected to seagrass vegetative reproductive organs like leaves, rhizome, roots and flowers. Lacunae have also function as place for gas exchange process, and very important for seagrass photosynthesis. Range of mesophyll cells thickness are 471.13$778.85 \mu \mathrm{m}$.

Epidermis forms a continuous layer on the rhizome surface and has a cuticle on the outer wall to provide mechanical protection (Kuo and den Hartog., 2006) . Rhizome epidermis thickness are 47.39-152.72 $\mu \mathrm{m}$. Between epidermis and endodermis layer, there is cortex which is composed by colenkim and parenchymal cells. Thickness of cortex cells are 273,99-384 $\mu \mathrm{m}$. Stele (cylinder center) serves to give strength for rhizome and thickness of $T$. hemprichii stele are 60.62-103.85 $\mu \mathrm{m}$.

The seagrass tissue histology showed that there were black dots in leaf and rhizome tissue (Figure 5 and 6). Refer to Arisandy et al. (2012) (Figure 7), black dot is an indicator that there is a heavy metal $(\mathrm{Pb})$ in seagrass tissue and high concentration of $\mathrm{Pb}$ has damaged the tissue resulted a necrosis (Figure 7 ). Seagrass tissue in all station showed better condition (Figure 5 and 6), when compared to Arisandy et al. (2012), it's showed that seagrasss tissue may tolerate, when low exposure of heavy metal in environment. The highest of heavy metal exposure from environment may damage effect for seagrass tissue (Noviariny et al., 2015). 



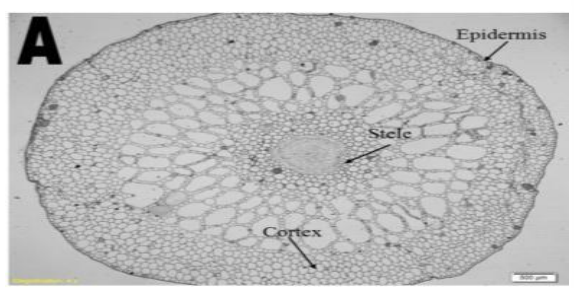

Station 1

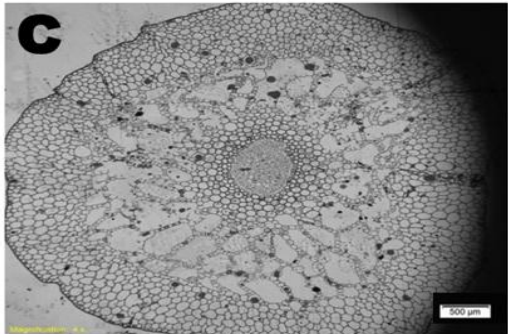

Station 3

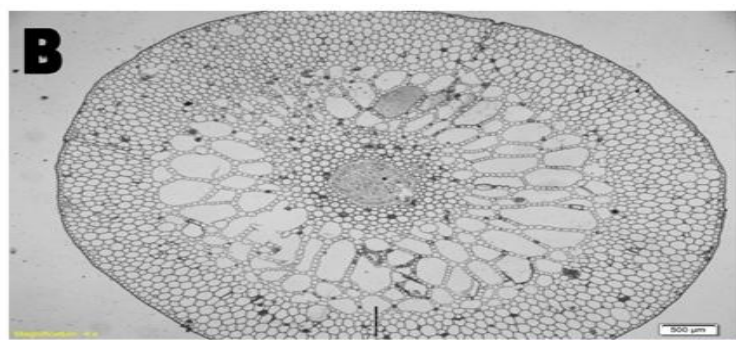

Station 2

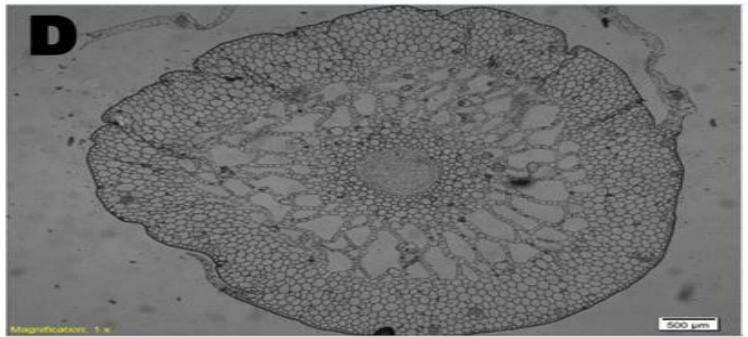

Station 4

Figure 6. Histological sampel of Seagrass rhizome tissue Thalassia hemprichii

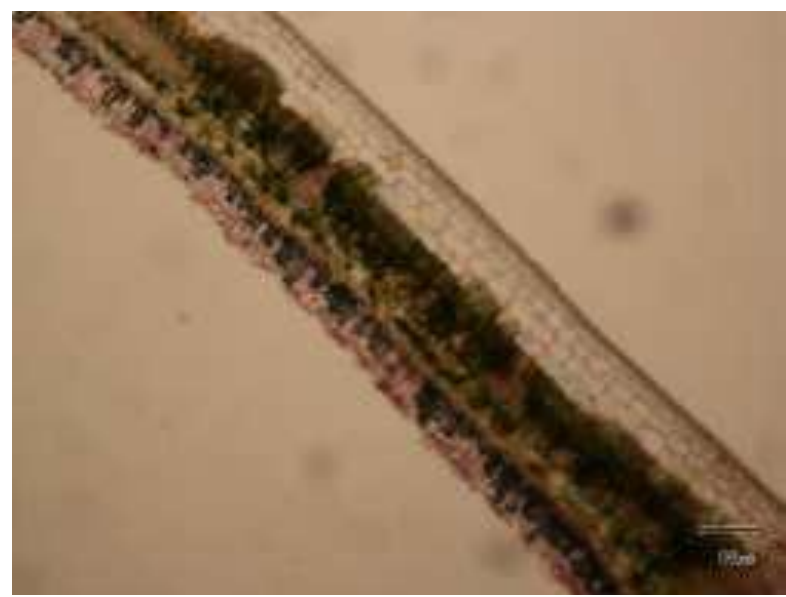

Figure 7. Condition of seagrass leaf tissue necrosis (Arisandy et al., 2012)

\section{Conclusion}

The growth rate of $T$. hemprichii varied in research station as a response of different nutrient content in environment. Bioaccumulation of heavy metals in seagrass tissue were not correlated with heavy metals concentration in the environment. Histological analysis showed that there were no tissue damage in T. hemprichii.

\section{References}

Ahmad , Fasmi.2009. Tingkat Pencemaran Logam Berat dalam Air Laut dan Sedimen di Perairan Pulau Muna, Kabaena, dan Buton Sulawesi Tenggara. Makara Sains.13(2):117-124.
APHA. 2012. Standard Method For The Examination of Water and Waste Wayer. 22 ${ }^{\text {th }}$ Edition. American Public Health Association. Washington DC (US): Environmental Protection Agency Press.

Alloway, B.J. \& Ayres, D.C. 1995. Chemical Principle of Environmental Pollution. London: Chapman and Hall. 102(1):216-218. doi: 10.1023/A:100498 6209096

Alutoin, S., Boberg, J., Nystrom, M. \& Tedengren, M. 2001. Effects of The Multiple Stressors Copper and Reduced Salinity on The Metabolism of The Hermatypic Coral Porites lutea. Mar Environ Res 52: 289-299. doi: 10.1016/S01411136(01)00105-2 
Arisandy, K.R., EY, Herawati., \& Suprayitno, E. 2012. Akumulasi Logam Berat Timbal (Pb) dan Gambaran Histologi pada Jaringan Avicenia marina (forsk.) Vierh di Perairan Pantai Jawa Timur. J. Pen. Perikan. 1:15-25

Burkholder, J.M., Tomasko, D.A. \& Touchette, B.W. 2007. Seagrasses and Eutrophication. J. Exp. Mar. Bio.l Ecol. 350:46-72. doi: 10.1016/j. jembe.2007.06.024

[CCME] Canadian Council of Ministers of The Environment. 1991. Interim Canadian Environmental Quality Criteria for Contaminated Sites.55.

Christianen, M.J.A., Van Belzen,J., Herman, P.M.J., Van Katwijk, M.M., Lamers, L.P.M., Van Leent, P.J.M \& Bouma T.J. 2013. Low-Canopy Seagrass Beds Still Provide Important Coastal Protection Services. PLOS ONE. 8 (5): e62413. doi : http://dx.doi.org/10.1371/journal.pone.0 062413

Christianen, M.J.A., Herman, P.M.J., Bouma T.J, Lamers, L.P.M, Van Katwijk,M.M, Van der Heide T, Mumby, P.J., Silliman, B.R., Engelhard S.L., Van de Kerk, Kiswara W, \& Van de Koppel J. 2014. Habitat collapse due to overgrazing threatens turtle conservation in marine protected areas. Proceeding of The Royal Society. B. 281, 20132890. doi: 10.10 98/rspb.2013.2890

D'Souza, C. Peretiatko, R.2002 The nexus between industrialization and environment: A case study of Indian enterprises. Environ. Manag. Health .3:8097.

Effendi, H. 2003. Telaah Kualitas Air. Yogyakarta: Kanisius.

Govers, L.L, Lamers, L.P.M., Bourna, T.J, Eygensteyn, De Brouwer, J.H.F., Hendriks, A.J, Huijbers, C.M, \& Van Katwijk, M.M. 2014. Seagrasses As Indicators for Coastal Trace Metal Pollution: A Global Meta-Analysis Serving As a Benchmark, and a Caribbean Case Study. Environ. Pollut. 195:210-217. doi: 10.1016/j.envpol.2014.08. 028

Heck, K.L., Hays, G., \& Orth, R.J. 2003. Critical evaluation of the nursery role hypothesis for seagrass meadows. Mar. Ecol. Prog. Ser. 253:123-136.

Kamaruzzaman, B.Y., Ong, M.C., Jalal, K.C.A, Shahbudin, S., \& Nor, O.M. 2008. Accumulation of Lead and Copper in Rhizophora apiculata from Setiu Mangrove Forest. J. Environ. Biol. 821-824.

Kawaroe M, Jaya, I. \& Indarto, H. 2008. Rekayasa Teknologi Transplantasi Lamun pada Jenis Enhalus acoroides dan Thalassia hemprichii di Kepulauan Seribu DKI Jakarta [Laporan]. Lembaga Penelitian dan Pengabdian Masyarakat Institut Pertanian Bogor.

Kawaroe, M., Nugraha, A.J., Juraij.2016a. Ekosistem Padang Lamun. Bogor: IPB Press.

Kawaroe, M., Nugraha, A.H., Juraij, Tasabaramo, I.A. 2016b. Seagrass biodiversity at three marine ecoregions of Indonesia: Sunda Shelf, Sulawesi Sea, Banda Sea. Biodiv. 17(2): 585-591 doi:10.13057/biodiv/d170228

Kiswara, W. 2010. Studi Pendahuluan: Potensi Padang Lamun sebagai Karbon Rosot dan Penyerapan Karbon di Pulau Pari, Teluk Jakarta. J. Osean dan Limno di Indo. 36(3): 361-376.

KMNLH (Kantor Menteri Negara Lingkungan Hidup). 2004. Keputusan Menteri Negara Lingkungan Hidup No.51 Tahun 2004 Tentang Baku Mutu Air Laut. Kementerian Negara dan Lingkungan Hidup. Jakarta.

Koch, E.W, Booth, D.M, \& Palinkas, C. 2012. Seagrasses and the ecosystem service of shoreline protection (or is it sediment stabilization?). In: Creed, J.C., \& Oigman Pszczol, S.S. (Eds.), Proc. 10th Int. Seagrass Biology Workshop (ISBW10), 25-30 Nov. 2012. Armac, ão dos Búzios, Brazil. Instituto Biodiversidade Marinha, Rio deJaneiro, Brazil, $108 \mathrm{hlm}$.

Kuo, J \& den Hartog. 2006. Seagrass Morphology, Anatomy and Ultrastructure. In: Larkum, A.W.D., Orth, R.J., \& Duarte, C.M. (Eds.). Seagrasses: Biology, Ecology and Conservation. Esplores: Springer. page: 53

Lee, K.-S., Dunton, K.H., 1997. Effect of in situ light reduction on the maintenance,growth and partitioning of carbon resources in Thalassia testudinum banks ex König. J. Exp. Mar. Biol. Ecol. 210 (1), 53-73.

Lee, K.S, Short, F.T \& Burdick, D.M. 2004. Development of a Nutrient Pollution Indicator Using The Seagrass, Zostera marina, Along Nutrient Gradients in Three New England Estuaries. Aquat. Bot. 78:197-216. doi: 10.10 16/j.aquabot.2003.09.010 
Li, Q., Yu, Z., Chu, B., Zhang, N., Cai, S. \& Fang, J. 2007. Heavy Metals in Coastal Wetland Sediments of The Pearl River Estuary, China. Environ. Pollut. 149:158-164. doi: 10.1016/j.envpol. 2007.01.006

Macinnis-NG, C.M.O \& Ralph, P.J. 2004. Variations in Sensitivy to Copper and Zinc Amongst Three Populations of The Seagrass Zostera capricorni. Exp. Mar. Bio. Ecol. 02:63-83. doi: 10.1016 /S0025-326X(01)003009

McFarlane, G.R \& Burchett, M.D. 2002. Toxicity, Growth, and Accumulation Relationship of Copper, Lead and Zinc in The Grey Mangrove Avicennia marina (Forsk.) Veirh.Mar Environ. Res. 54:65-84. doi: 10.1016/S01411136(02)00095-8

Mcleod,E., Chmura, G.L, Bouillon, Salm, R., Björk, M., Duarte, C.M., Lovelock, C.E., Schlesinger W.H \& Silliman, B.R. 2011. A blueprint for blue carbon: toward an improved understanding of the role of vegetated coastal habitats in sequestering C02. Front. Ecol. Environ. 9:552-560. doi: 10.1890/110004

Noviarini, W., Ermavitalini, D. 2015. Analisa Kerusakan Jaringan Akar Lamun Thalassia hemprichii yang Terpapar Logam Berat Kadmium (Cd). Jur Sains dan Seni ITS. 4(2): 71-74

Rollon, R.N., Cayabyab, N.P., \& Fortes, M.D. 2001. Vegetative Dynamics and Sexual Reproduction of Monospesific Thalassia hemprichii Meadows in The Kalayaan Island Group. Aquat Bot. 71:239-246. doi: 10.1016/S0304-3770/01 $00178-4$

Rustam A. 2014. Kontribusi Lamun Dalam Regulasi Karbon dan Stabilisasi Ekosistem.[Disertasi]: Institut Pertanian Bogor.

Saas, JE. 1951. Botanical Microtechnique. 2nd ed. lowa: The lowa State Colledge Press.

Short, F.T., 1983. The seagrass, Zostera marina L plantmorphology and bed structure in relation to sediment ammonium in lzembek lagoon, Alaska. Aquat. Bot. 16, 149-161.

Short, F., Carruthers, T., Dennison, W., \& Waycott, M., 2007. Global Seagrass Distribution and
Diversity: a Bioregional Model. Exp. Mar. Biol. Ecol. 350:3-20. doi: 10.1016/j.jembe.2007. 06.012

Short \& Duarte. 2001. Methods For The Measurement of Seagrass and Growth Production. Di dalam:Short FT, Coles RG, editor. Global Seagrass Research Methods. Elselvier.

Udy, J.W. \& Dennison, W.C. 1997. Growth and physiological responses ofn three seagrass spesies to elevated sediment nutrients in Moreton Bay Australia. J. Experim. Mar. Bio. Eco. 217:253-277. doi: 10.1016/S0022-09 81(97)00060-9

Unsworth, R.K.F., Collier C.J., Waycott M, McKenzie L.J, \& Cullen-Unsworth, LC. 2015. A Framework for The Ressilience of Seagrass Ecosystem. Mar. Pol. Bull. doi: 10.1016/j. marpolbul.2015.08.016

Van Tussenbroek, B.I, Vonk, J.A., Stapel, J., Erftemeijer, P.L.A, Middelburg, J.J. \& Zieman J.C. 2006. The biology of Thalassia: paradigms and recent advances in research. In: Larkum, A.W.D., Orth, R.J., \& Duarte, C.M. (Eds.). Seagrasses: Biology, Ecology and Conservation. Dordrecht: Springer. pp:409439.

Vermaat, J.E., Agawin, N.S.R, Duarte, C.M., Fortes M.D, Marba, N. \& Uri, J.S. 1995. Meadow Maintenance, Growth and Productivity of A Mixed Philippine Seagrass Bed. Mar. Eco. Prog. Ser. 124:215-225. doi: 10.3354/meps124215

Vonk, J.A, Christianen, M.J.A, Stape, J. \& O'Brien K.R. 2015. What Lies Beneath: Why Knowledge of Belowground Biomass Dynamic is Crusial to Effective Seagrass Management. Eco Indic. 57:259-267. doi: 10.1016/j. ecolind.2015.05. 008

Zhang, J., Huang, X. \& Jiang, Z. 2014. Physiological Responses of The Seagrass Thalassia hemprichii (Ehrenb.) Aschers as Indicators of Nutrient Loading. Mar. Pol. Bul. 83:508-515. doi: 10.1016/j.marpolbul.2013.12.056

Zhanzhou, X.L.H, Xiaoping, H., Aijia, Z. \& Si, Z. 2009. Growth Strategy of Seagrass Thalassia hemprichii in Xincun Bay Near Hainan Island of China. Mar .Scien. Bul. 11(1):53-61 